\title{
Cannabis Regulation and Development: Fair(er) Trade Options for Emerging Legal Markets
}

\author{
David Bewley-Taylor, Martin Jelsma and Sylvia Kay
}

\begin{abstract}
Significant policy shifts have led to an unprecedented boom in medical cannabis markets, while a growing number of countries are moving towards the legal regulation of adult non-medical use. This trend is likely to bring a range of benefits. Yet there are growing concerns over the many for-profit cannabis companies from the global North that are aggressively competing to capture the licit spaces now opening in the multibillion-dollar global cannabis market. This threatens to push small-scale traditional farmers from the global South out of the emerging legal markets. Those trying to transition out of illegality face huge difficulties due to a combination of the legacy of criminalisation and administrative barriers to entry. Conquering and protecting spaces for small-scale farmers within the current overheated and corporate-driven market will require affirmative action, regulation of foreign investment, and welldesigned legislative and market strategies. This policy comment explores the unfolding market dynamics from a development perspective and offers a set of guiding principles and policy proposals upon which a more equitable, fair(er) trade cannabis regulation model can be built.
\end{abstract}

Introduction ${ }^{1}$

Policy changes over the past five years or so have dramatically reshaped the global cannabis market. Not only has there been an unprecedented boom in medical markets, but, following policy shifts in several jurisdictions, a growing number of countries are also preparing for the legal regulation of adult

1 This article draws on and develops ideas and arguments contained within Martin Jelsma, Sylvia Kay and David Bewley-Taylor (2019) Fair(er) Trade Options for the Cannabis Market, Cannabis Innovate, Policy Report 1, London/Swansea, March. Thanks go to the anonymous International Development Policy reviewers for their constructive comments and feedback. As ever, any errors of fact or interpretation remain those of the authors.

(C) DAVID BEWLEY-TAYLOR, MARTIN JELSMA AND SYLVIA KAY, 2020 ～DOI:10.1163/9789004440494_007 
non-medical use. Such moves are triggered by the recognition that decades of repressive policies have proved ineffective and have had grave negative consequences. A reckoning with these past failures and a shift towards a new model for cannabis regulation look set to bring a clear range of benefits in terms of health and human rights, and potential reductions in crime and over-incarceration. Nonetheless, there are also growing reservations regarding unfolding market dynamics. Among these is a concern over the many for-profit cannabis companies from the global North ${ }^{2}$ that are aggressively competing to capture the licit spaces now rapidly opening in the multibilliondollar global cannabis market. This threatens to push small-scale and marginalised traditional farmers from countries such as Colombia, Mexico, Jamaica, St Vincent and the Grenadines, Morocco, South Africa, India, Nepal or Thailand out of the emerging markets, even though they have supplied illicit markets for decades. ${ }^{3}$

It is, therefore, vital amongst important and timely discussions surrounding both patient access to medical cannabis and the emerging structure of regulated markets for recreational use, particularly within the global North, that the socio-economic needs and interests of traditional cannabis producers in the global South are not overlooked. The millions of people around the world currently depending on the illicit market for their livelihoods should not be left behind in this historic transition. There should be no reason why, with the right public policies in place, small-scale farmers cannot benefit from these market openings, working in mutually beneficial partnership with or alongside ethical companies. Such an approach would not only move beyond standard corporate social responsibility (CSR), it would also align with government obligations to end poverty, hunger and the causes of structural inequality and discrimination in the context of the 2030 Sustainable Development Agenda. The 2016 United Nations (UN) General Assembly Special Session on the World Drug Problem (UNGASS) reaffirmed a spirit of 'shared responsibility' in that regard (UN General Assembly, 2016).

2 The terms global North and global South are used here to refer to the geographical global North/South divide and the associated unequal distribution of economic and political power loosely based on the so-called Brandt Line. That said, a broader non-geographical interpretation is also applicable whereby 'power-conscious readings of place [...] challenge nationbased models of the Global North (First World) and the Global South (Third World)' and suggest that 'one may exist within the other' (Trefzer et al., 2014, 1).

3 While these are countries where, to varying degrees, there is currently some discussion about market transition, many more states from the global South can be regarded as traditional producer states. See Figure 6.4. 
Drawing on evidence from some of the countries mentioned above, ${ }^{4}$ this policy comment argues that policymakers at a range of governance levels should grasp the opportunities afforded by the dramatic shifts in the cannabis market to help shape its growth and to ensure that it will enable cannabis producers in the global South to transition out of illegality. From a sustainable development perspective, this would mean putting in place standards and charting a course that triggers a race to the top, not to the bottom. Moving beyond a set of minimum legal standards would pave the way for an approach that is fairer and more equitable than is currently the case within the nascent licit cannabis market; what we call a fair(er) trade cannabis model. Conscious of the definitional complexities associated with the terms '"Fairtrade", 'Fair Trade,' 'Fairly Traded' or other variations of spelling' and the 'contest for meaning between these terms' (Tiffen, 2019; Walton, 2010; Ehrlich, 2018) yet drawing on many of the high-order principles developed by what might be called the 'Fair Trade Movement', such a model would, put simply, be built around a rights-based, inclusive and environmentally sustainable approach to market engagement.

The notion of fair(er) trade cannabis is not as far-fetched as it might at first appear. A 2018 review of the cannabis market in the United States (US), for example, found about a dozen nationwide voluntary cannabis-specific standards-setting organisations that claim to certify cannabis as 'ethical'. What this means in practice, however, varies considerably. And this also highlights problems surrounding voluntary codes/challenges in (inter)national standard setting that are not unique to the cannabis market. ${ }^{6}$ Beginning with a brief overview of the current situation relating to both medical and recreational cannabis, this policy comment moves on to discuss some of the barriers pertaining to the transition from illegality for small-scale cannabis farmers. Having explored some of the key issues surrounding cannabis and development,

4 While small-scale and marginalised traditional farmers from a range of countries are being, or are at risk of being, pushed out of the emerging market, solid empirical data on the process is uneven. Consequently, here the focus is largely on the Americas where information is currently more widely available.

5 These include the Cannabis Certification Council (ccc), Certified Kind, Clean Green, EnviroCan, the Foundation of Cannabis Unified Standards, Patient Focused Certification (PFC), Resource Innovation Initiative (RII), Oregon Sungrown Certified, and The Cannabis Conservancy (TCC), amongst others (Bennett, 2018b).

6 For example, they are industry-driven, rather than worker- or social movement-driven; lack transparent governance structures and consultation- or standard-setting processes; contain weak monitoring, evaluation and accountability mechanisms; and do not include methods for identifying and incorporating perspectives of traditionally marginalised groups. 
the chapter concludes by highlighting several considerations, and offers a set of key principles to help guide the promotion and development of fair(er) trade cannabis.

\section{Legal Market Expansion}

Beginning with California in 1996, the medicinal use of cannabis has been legal for some time in numerous US states, with - as of October 2019-33 states and the District of Columbia permitting patient access. Elsewhere, at the national level, the medical cannabis market has been booming in recent years. Almost every month another country moves to regulate. ${ }^{7}$ Although countries such as Israel, Canada and the Netherlands might be regarded as early adopters, with cannabis for medical use permitted since 1992, 1999 and 2001, respectively, rapid expansion has been taking place across Europe (Germany, Greece, the Czech Republic, Poland, Slovenia, Luxembourg, Switzerland), Oceania (Australia and New Zealand) and Latin America (Uruguay, Colombia, Chile, Argentina, Mexico, Peru, Paraguay), despite many shortcomings in the regulatory frameworks in place in most of the countries concerned. This trend is now also becoming visible in the Caribbean, Africa (Lamer, 2018) and Asia, in countries such as Jamaica, St Vincent and the Grenadines, Barbados, Trinidad and Tobago, the US Virgin Islands, India, South Africa, Lesotho, Ghana, Zambia, Zimbabwe, Swaziland, the Philippines and Thailand (Aguilar et al., 2018; Pascual, 2019) (see Figure 6.1).

Moving beyond medicinal uses, beginning with policy shifts in 2012, eleven US states plus the District of Columbia have now approved ballot initiatives or passed laws to regulate cannabis. Uruguay (2013) and Canada (2018) have implemented laws at the national level (see Figure 6.1). These new frameworks for the legal regulation of the whole cannabis market, including non-medical or 'adult' or 'recreational' uses, are contributing to fresh debate elsewhere in the world. For example, while many countries remain committed to punitive prohibition, cannabis regulation is on the agenda of the governments of Mexico and of Luxembourg, and in New Zealand the governing coalition has committed to a ballot initiative by 2020 on whether to legalise non-medical cannabis. The Dutch government will be permitting a four-year programme of local experiments in regulated cannabis production to supply

7 This policy comment does not cover questions concerning the clinical efficacy of medicinal cannabis. An overview of the latest scientific evidence can be found, for example, in NASEM, 2017; EMCDDA, 2018; and Hall, 2018. 

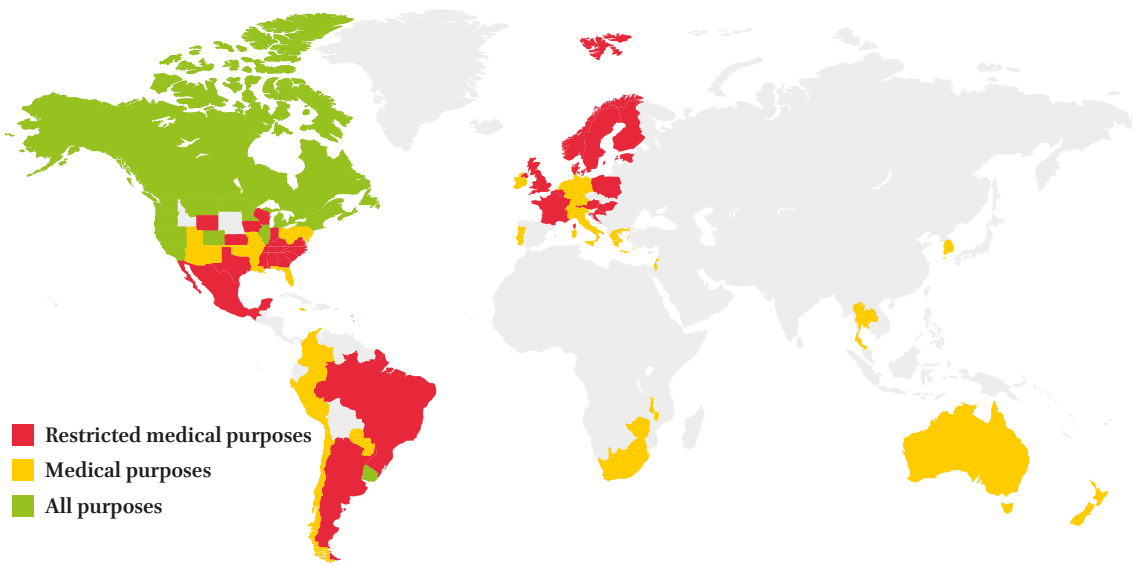

FIGURE 6.1 Cannabis regulation world map SOURCE: CREATED BY AUTHORS

the 'coffeeshops' where purchase and use has been tolerated since the 199os. Similar experiments are also to take place in Switzerland, and multiple regulatory proposals have emerged at municipal and regional levels in other European countries (Blickman et al., 2019). Within the US, additional state ballot initiatives are being planned, and more state legislatures are considering cannabis regulation bills. In the Caribbean region, the 2018 CARICOM Regional Commission on Marijuana concluded that the UN-based 'prohibitionist regime on cannabis/marijuana is not fit for purpose', recommending 'significant changes to the laws of the region to enable the dismantling of this regime [...] that has proven to be ineffective, unjust and caused more harm than it sought to prevent' (CARICOM Regional Commission on Marijuana, 2018, 62). And, signalling a shift towards more liberal approaches to the drug, in December 2018 - following in the footsteps of Jamaica - St Vincent and the Grenadines as well as Antigua and Barbados adopted legislation regulating medical use and decriminalising possession and cultivation for any personal use (Jamaica Observer, 2018a; 2018b).

This policy trend towards legal regulation is likely to consolidate and spread to more jurisdictions. However, while the medical cannabis boom is-with certain conditions - justifiable under the existing UN drug control regime, there can be no doubt that the legal regulation of non-medical markets is out of compliance with provisions of the UN drug control treaties. As more jurisdictions move in this direction, treaty tensions will increase, and states will be obliged to explore options to reconcile such policy changes with their obligations under international law (Jelsma et al., 2018). 
These shifts in attitudes, and subsequently in policies, have generated considerable interest from the business community, including the pharmaceutical, tobacco, and alcohol industries and investment bankers and hedge funds. Despite the increasingly obvious existence of a speculative bubble, investment opportunities are especially attractive in the global South and traditional cannabis producing countries. Here, a combination of lower production costs, suitable cannabis plant varieties, possible medical cannabis export opportunities, and potential in-region consumer markets for both medical and recreational purposes has resulted in what has been referred to as a 'green rush' of investors and medical cannabis companies. Attracted to places such as Latin America and the Caribbean, these mostly Canadian companies are seeking to connect actual and potential demand in emerging consumer states within the western hemisphere and Europe with supply from traditional producer states, and reap the enormous profits that potentially go with it (Pascual, 2019).

Cannabis companies that went public on the Canadian stock exchange accumulated billions of dollars, triggering a financial bubble driven by highly speculative market predictions. Much of the capital generated from those share sales was invested in stock promotion, mergers, and acquisitions (Rendell and Kiladze, 2019), and part of it was used to establish new cultivation and production facilities in Southern countries or to buy up local licensed companies. To date, however, hardly any international trade in cannabis has actually materialised and clear signs of a bursting bubble became visible in the second half of 2019. The market value of Canada-based Canopy Growth, for example, still the world's largest cannabis company, dropped from USD 18 billion (CAD 24 billion) in April 2019 to about USD 5.5 billion (CAD 7.1 billion) in mid-November (Bloomberg, 2019).

Nothing of the 'green rush' billions has ended up with traditional cannabis growers in the global South, who struggle to get access to the corporate-driven market, and do so despite the intention within some governments to encourage smaller local groups to enter the market, both in terms of medical cannabis and further down the line in relation to more widespread recreational use in a range of jurisdictions.

It would seem only fair that those who- often for basic economic survival in the absence of other viable opportunities-have endured supplying the illicit 
cannabis market, those who were most affected by the 'war on drugs', and those who in many ways paved the way for recent policy changes should be first in line to benefit from the emergence of licit spaces in the market. Those trying to transition out of illegality, however, face huge difficulties due to a combination of the legacy of criminalisation and legal and administrative barriers to entry. Conquering and protecting spaces for small-scale farmers in traditional producing countries (Figures 6.2 and 6.3) in light of the current overheated and highly competitive global cannabis market dynamics will require affirmative action, regulation and control of foreign investment and transnational corporations, and well-designed legislative and market strategies. And, while not our focus here, the same holds true for black and Latino communities in the US or for ethnic minorities elsewhere that have been disproportionately affected by drug law enforcement (Dufton, 2017, pp. 225-248). As the market continues to emerge and find its shape in the global South, portents of the future can already be identified in the global North. Difficulties encountered in overcoming the legacy of punitive prohibition are being documented in the US and Canada, even in jurisdictions that-engaging with the concept of social justice-intended to give preferential access to those who had been involved in supplying the illicit market (Avins, 2019). Small cannabis growers in the global South (see Figure 6.4) face very similar, if not worse, obstacles to conquering a place in the licit market.

There are some positive developments. In late 2018, authorities in St Vincent and the Grenadines passed a Cannabis Cultivation Amnesty Bill as part of a suite of measures to support small-scale farmers who have been illegally cultivating and trading cannabis transition to become legal licenced growers of medicinal cannabis. Nevertheless, the business of securing a licence in St Vincent and the Grenadines as elsewhere in the Caribbean is expensive for small growers, and there are considerable additional set-up costs to meet standards, such as establishing security systems (including something as basic as fencing). Further expenses are incurred in seeking advice on and changing traditional cultivating techniques to adhere to Good Agricultural Practice standards and protocols. This means that there is a need to attract and rely on foreign capital. In Jamaica, for example, most of the 30 licences awarded by the Cannabis Licensing Authority (CLA) to cultivate and sell cannabis are said to be supported by a significant level of foreign backing. The same goes for the 170 applications conditionally approved. Such a dependence on outside investment means that appropriate framework conditions must be in place in order to solicit the right kind of investment and ensure that wealth is not extracted at the expense of local development and livelihoods. 


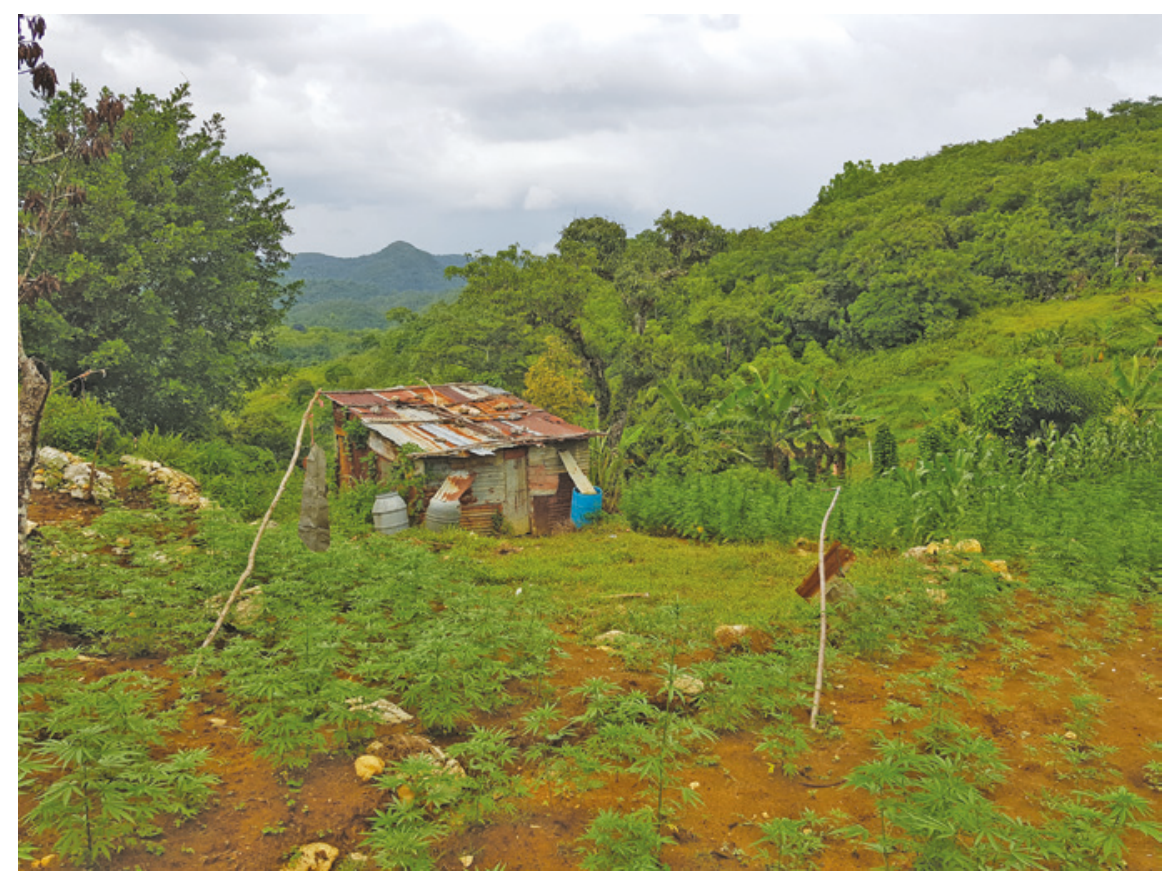

FIGURE 6.2 Illicit cannabis cultivation in Westmoreland, Jamaica SOURCE: PHOTO BY AUTHOR, MARTIN JELSMA, AUGUST 2018

Concern regarding the resulting asymmetry was, in many ways, foreshadowed by the CARICOM Marijuana Commission when it noted, 'Embracing cannabis/marijuana as a means of economic development is not without its challenges'. Adding more detail, it continued by stressing that, 'A serious concern is that a new system could place economic power and benefit too much in the hands of large, foreign business concerns, to the detriment of several stakeholders, including small farmers [...] cannabis has fuelled important economic gains and livelihoods for small farmers and traders, who now fear that liberalisation and legalisation might dis-empower them' (САRICOM Regional Commission on Marijuana, 2018, 56).

Some measures have been introduced to deal with these concerns, including stipulations on the kinds of partnerships and agreements into which foreign investors can enter. According to Jamaican law, for example, foreign companies are obliged to have local partners, who retain — on paper at leastmajority control. However, it is clear that the relationship with the sources and types of investment in the emerging cannabis market is an area that will need careful monitoring. This is especially true in the context of cannabis, where 


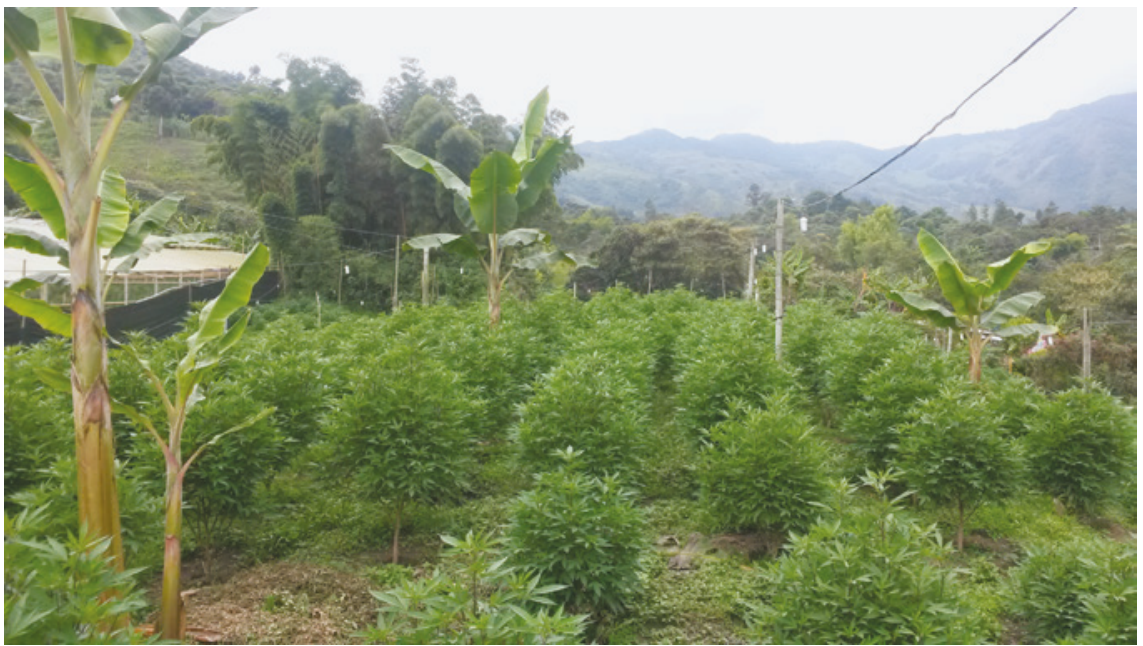

FIGURE 6.3 Illicit cannabis cultivation in Colombia SOURCE: PHOTO BY AUTHOR, MARTIN JELSMA, JUNE 2017

access to capital is already fraught with difficulties given the restrictions imposed by US banking regulations and the fact that cannabis is still illegal at the federal level. Since local Jamaican banks have ties to the US, they are unwilling to take on cannabis clients for fear of negative repercussions in the absence of correspondent banking regulations (Subramaniam, 2019). While this remains hugely challenging, the situation is evolving. St Vincent and the Grenadines has, for example, become the first country in the Caribbean to grant permission for licensed cultivators to open bank accounts with the majority stateowned Bank of St Vincent and the Grenadines. This opens up a door for smallscale farmers from the country (and other countries) to transition from the illegal to the legal market, or for those just wanting to get into the cannabis trade for the first time.

\section{5}

\section{Cannabis and Development}

Several countries have expressed an interest in using the rapidly opening licit spaces in the global market as an 'alternative development'—or, more appropriately, simply a development - opportunity for small farmers currently producing for the illicit market, contrasting this as a more viable alternative to failed 'crop substitution' projects implemented in the past. In fact, already during the negotiations in the late 195 os for the 1961 Single Convention on Narcotic 
Drugs, there was some recognition that the treaty obligation to eliminate illicit cultivation required the provision of alternative livelihood options for the communities involved. Morocco for example, having just gained independence, drew attention to the problem 'that thousands of people had for years been living on the cultivation of kif, and it was their main source of livelihood', and asked the international community for development assistance (UN CND, 1958, 28).

While 'alternative development' ( $\mathrm{AD}$ ) became a major issue for debate at the UN level for coca and opium poppy, only a handful of such projects have been set up for cannabis farmers. These have been in Lebanon, Morocco, Indonesia and the Philippines, although none have been successful. Repeated calls to the international donor community for more development assistance in this area, especially from African countries, have fallen on deaf ears. Donors do not seem to believe AD could work in the case of cannabis, nor does it rank high on the political agenda. The recent regulation trend, however, potentially offers a new perspective on providing licit (alternative) livelihood options for subsistence farmers currently dependent on the illicit cannabis economy.

For instance, a pilot project with rural communities has recently been initiated in Jamaica, representing an important first attempt to utilise the

$<10,000$ hectares

$>10,000$ hectares

FIGURE 6.4 Traditional producer countries

Notes: Producer countries with less than 10,0oo hectares: Brazil, Colombia, Ghana, Kenya, Kyrgyzstan, Lebanon, Lesotho, Nepal, Nigeria, Pakistan, Paraguay, St Vincent and the Grenadines, South Africa, Swaziland, Thailand.

Producer countries with more than 10,00o hectares: Afghanistan, India, Jamaica, Kazakhstan, Mongolia, Morocco, Mexico.

SOURCE: CREATED BY AUTHORS 
opening of licit spaces in the global cannabis market as an economic opportunity for small-scale farmers currently producing for the illicit market. In 2016, the CLA introduced a tiered licensing system for medical ganja, meant to 'enfranchise the small farmers who had previously been subject to significant punitive action by law enforcement agencies' (Jones, Porter and Bishop, 2017, 115). Jamaican Prime Minister Andrew Holness announced that the government would, in the first quarter of 2019, 'unveil a development programme for farmers in the ganja sector [...] to ensure the small farmers in the sector are protected as the global marijuana industry expands. [...] because it is a real fear that as that industry emerges, becomes more corporatized, that the original ganja man, the original farmer, could very well be left out of the gains and the benefits' (Holness, 2019). The ClA 'Alternative Development Project' (ADP) is being developed in collaboration with the Westmoreland Hemp \& Ganja Farmers Association and the St Elizabeth Maroon community and is 'geared towards transitioning current illicit ganja farmers into the legal regulated industry' (CLA, 2O17). This goal was emphasised in April 2019 by J.C. Hutchinson, minister without portfolio at the Ministry of Industry, Commerce, Agriculture and Fisheries. Referring to the ADP rollout, he stressed that 'cannabis is one of the crops which the government is making sure that the small farmers are involved in growing legally' (Ferguson, 2019). The long delay, limited implementation and ongoing confusion about its status-as of October 2019 it has not been officially launched (Jamaica Observer, 2019) - makes even an initial evaluation of the ADP difficult. Nonetheless, the scheme is worth monitoring, especially considering the fate of programmes in other parts of the world.

Several other countries that have recently chosen to allow the use of cannabis for medicinal purposes have attempted to introduce preferential access schemes for existing small-scale farmers and restrictions on foreign investments. Unfortunately, these initial attempts are yet to prove their capacity to enable local cultivators to genuinely overcome the difficult hurdles faced when entering the competitive global medical cannabis market. Meanwhile, foreign, private companies - benefiting from governmental apathy and sometimes even the assistance of local politicians with business interests - stand ready to invade and capture these market spaces with millions of dollars to invest (Barjas, 2018). Despite perhaps good intentions and public-facing protestations concerning engagement with local communities, the track record of many medical cannabis companies currently operating in places such as Jamaica and Colombia has fallen far short of commitments made (Martínez Rivera, 2019). 
The United Nations Office on Drugs and Crime 2006 World Drug Report concluded: "The world has failed to come to terms with cannabis as a drug. In some countries, cannabis use and trafficking are taken very seriously, while in others, they are virtually ignored. This incongruity undermines the credibility of the international system, and the time for resolving global ambivalence on the issue is long overdue. Either the gap between the letter and spirit of the Single Convention, so manifest with cannabis, needs to be bridged, or parties to the Convention need to discuss re-defining the status of cannabis' (UNODC, 2006, 186). Historic policy changes are now reshaping the global cannabis market, and the gradual dismantling of the prohibitive regime that reigned in past decades is a welcome development. It would be a dramatic outcome, however, if the legally regulated medical and non-medical markets that are rising from the ashes of global drug prohibition ultimately lead to what prohibition intended, but never succeeded in achieving: the destruction of the remnants of traditional cannabis cultures that barely managed to survive, and the eradication of the illicit cannabis survival economies in the global South. The construction of the global cannabis prohibition regime was a historic mistake with severe consequences. But if the transition towards a legally regulated market results in a corporate takeover that concentrates profits in the pockets of a handful of Big Pharma, Agro, and cannabis companies and pushes small-scale farmers in the global South out of business, another historic mistake is already in the making.

Ensuring that fair(er) trade principles guide this transition is a responsibility for governments and the cannabis industry alike. Far from being a purely quixotic, benevolent endeavour, benefits can be derived for both. For governments in the global South, for example, carefully structured producer frameworks have the potential to help fulfil human rights commitments and to achieve hitherto elusive development outcomes in marginalised communities, thereby contributing to the achievement of the Sustainable Development Goals (SDG s) as committed to at the UN level. Kate Gilmore, Deputy High Commissioner, Office of the UN High Commissioner for Human Rights, when introducing the draft of the Declaration on the Rights of Peasants and Other People Working in Rural Areas in April 2018, referred to the 2030 Agenda for Sustainable Development and its promise to leave no one behind': 'Promises that no one is to be left behind by discrimination nor poverty; or left out through marginalization; or forgotten because their truths are inconvenient to the privileged. Yet, those universal promises have not been upheld. Peasants and other people working in rural areas have been left behind' (Gilmore, 2018). 
And there is a real risk that this will be especially the case now for those dependent on illicit cannabis cultivation.

Going beyond standard CSR, companies in the cannabis sector are likely to benefit from the market appeal of ethically sourced, or fair(er) trade, cannabis. While that may be the case, as with regulative frameworks around other commodities industry voluntarism is only likely to go so far, and appropriate structures will thus necessitate a degree of public policy monitoring and evaluation. The issue is, however, also important for the drug policy reform movement, which has played a crucial role in triggering these policy changes by rightfully pointing out the many negative consequences of prohibition. Now that the wheels of change are turning, it is time to prioritise advocacy for a fair(er) trade cannabis market, to protect the rights of small-scale farmers and others who bore the brunt of repressive approaches, and to ensure a place for them in the emerging licit markets.

The challenges are manifold, and the political, legislative and commercial landscapes are fluid. Mindful of the intricate, cross-cutting and complex nature of the commercial and legal environment, careful thought must be given to a set of interconnected frameworks relating to producers, consumers, quality and standards, as well as finance and trade policies. In this regard, lessons can be drawn from other global commodity markets and the ongoing struggles of small farmers to survive amidst deregulation and globalisation, free trade and investment agreements, and unrestricted corporate capture of markets by transnational corporations. In fact, in many instances, neo-liberal trends in the global economy have directly contributed to an expansion of illicit economies. Dramatic price crashes of traditional export commodities such as coffee, cacao and bananas have forced many small farmers in the global South to take refuge in the illicit cultivation of opium, coca and cannabis - the few remaining agrarian products where they have a comparative advantage. Their illegal nature can offer them higher prices and better chances of survival. In all three cases, fair trade markets have emerged with accompanying certification mechanisms to preserve at least pockets of these global markets in which some rural communities have been able to survive.

Coffee, cacao and bananas require climatological conditions that prevent a transfer of production to the global North, while cannabis can basically be grown anywhere. The illicit and the emerging licit cannabis markets have both experienced a process of import substitution in the major Northern consumption markets with rapidly expanding greenhouse and indoor cultivation. This poses additional challenges for traditional cannabis growers in the global South and for the development of comparable fair(er) trade scenarios to protect them. More emphasis will have to be given to arguments 
around 'ethical consumerism' (Bennett, 2018a); branding based on quality advantages of native cannabis strains and traditional cultivation techniques, using 'geographical indications' (Benavente, 2013) or 'denominations of origin' certification for example (European Union, 2016); the significant carbon footprint disadvantages of indoor/greenhouse production facilities (Milman, 2017); and so on.

On the other hand, fair trade pockets for coffee, cacao and banana had to be reconquered in an already established fully liberalised market, while the transition from an illicit to a licit global cannabis market is still in an incipient stage. Theoretically, this may offer better conditions to shape the market's contours and introduce social justice and fair(er) trade principles from the outset. While the initial 'green rush' and rapid growth of big cannabis companies instilled fear of an early corporate capture of the emerging market, the recent burst of the speculative bubble may indicate that it is not yet too late to start a serious discussion about how to create a more equitable global cannabis market. Quite a few Southern traditional supplier countries of the illicit cannabis market have recently adopted medical cannabis legislation, struggling to still get a piece of the global medical pie. However, as long as major producers such as Colombia, Jamaica, St Vincent and the Grenadines, Morocco, South Africa, Lebanon, India, Nepal or Thailand remain unwilling to also legally regulate cannabis for non-medical purposes, millions of small farmers will still lose their livelihoods. Preventing that scenario will require the proactive engagement of those countries in regional and global forums soon, with the aim of opening the debate about an international cannabis trade regime and defying the strictures of the current UN drug control treaties.

Nonetheless, drawing on the initial discussions introduced here and explored more fully elsewhere (Jelsma et al., 2019), we believe that it is possible to develop a set of guiding principles and policy proposals upon which a fair(er) trade cannabis model can be built. Foundational principles include:

- A commitment to solidarity and social justice, with initiatives going beyond pure profit and business making opportunities to integrate ethical concerns as a foundational part of the operation.

- Producer empowerment and community benefit sharing through more equitable terms of trade, in which producers are not just seen as providers of raw materials but as value creators.

- Environmental sustainability standards in relation to the use of energy, water, and agricultural inputs.

- Labour protections to ensure worker safety, health, and satisfaction.

- Democratic control, participation and decision-making processes, through inclusive business models and systems of worker-driven social responsibility. 
- Transparency and traceability in the operation of the cannabis market and supply chain.

- Longer-term strategies, with special attention placed on marginalised communities and rural areas in (traditional) producing countries.

- Respect for social history and the role of cannabis in the cultural and religious identities and practices of traditional growing communities.

Based on those overarching principles, several concrete policy measures can be considered:

- Quotas that stipulate that a certain percentage of cannabis product must be sourced from small growers;

- Minimum pricing for delivery of cannabis so that producers are guaranteed a specified income stream;

- Affirmative licensing laws that prioritise, in the first instance, small and traditional cultivators to give them a head start in the market;

- A development fund from the fees collected from the issuing of licenses and/ or other revenue, which could be put back into cannabis growing communities and regions;

- Lower barriers to entry for small and medium-sized producers in terms of administrative, compliance and security costs;

- Restrictions on foreign investment with regard to the acquisition of licenses, company ownership, and intellectual property rights over local cannabis strains and products;

- Enable a legal national and export market for cannabis-based alternative health products alongside high-standard pharmaceutical prescription medicines;

- Encourage cannabis growers to organise and register themselves as cooperatives to pool resources and coordinate lobbying efforts and negotiations with governments and companies;

- Enact land reform programmes where cannabis growers currently find themselves without access to land or security of tenure;

- An amnesty and the expungement of criminal records to facilitate cannabis growers to transition out of illegality.

These proposed principles and policy measures are non-hierarchical and nonexhaustive. They are intended to stimulate further debate and reflection as the licit cannabis market evolves, although there will certainly be a need for cultural sensitivity and flexibility based on the diversity of profiles of growers and consumers in different regions. Above all, however, they are a call to

8 We acknowledge that in many parts of the world, land reform is complex and problematic. Nonetheless, it remains an important policy measure for consideration. 
policymakers, development agencies and investors to start taking the issue of fair(er) trade cannabis seriously and to transform the idea from a utopia into a reality.

\section{References}

Aguilar, S., V. Gutiérrez, L. Sánchez, and M. Nougier (2018) Medicinal Cannabis Policies and Practices around the World, IDPC/MUCD Briefing Paper, April.

Avins, J. (2019) 'In the Age of Luxury Cannabis, It's Time to Talk about Drug War Reparations', Quartz, 25 January, https:/qz.com/1482349/weed-and-reparations/ (accessed on 4 March 2019).

Barjas, J. (2018) ' “Investments that Generate Hope”: Inside Colombia's Canadian Cannabis Boom', CannabisWire, 5 December, https://cannabiswire.com/2018/12/05/ investments-that-generate-hope-inside-colombias-canadian-cannabis-boom/ (accessed on 4 March 2019).

Benavente, D. (2013) The Economics of Geographical Indications (Geneva: Graduate Institute Publications), new online edition: http://books.openedition.org/iheid/525 (accessed on 27 April 2020).

Bennett, E. (2018a) 'Extending Ethical Consumerism Theory to Semi-legal Sectors: Insights from Recreational Cannabis', Agriculture and Human Values, 35(2), pp. 295-317.

Bennett, E. (2018b) 'Prohibition, Legalization, and Political Consumerism: Insights from the U.S. and Canadian Cannabis Markets', in Boström, M., M. Micheletti, and P. Oosterveer (eds), The Oxford Handbook of Political Consumerism (Oxford: Oxford University Press).

Blickman, T, K. Sandwell and D. Putri (2019) Cannabis in the City: Developments in Local Cannabis Regulation in Europe (Amsterdam: Transnational Institute).

Bloomberg (2019) 'The Pot Stock Bubble has Burst. Here's Why', 16 November, Los Angeles Times, https://www.latimes.com/business/story/2019-11-16/pot-stock-bubblehas-burst (accessed on 7 December 2019).

CARICOM Regional Commission on Marijuana (2018) Report of the CARICOM Regional Commission on Marijuana 2018: Waiting to Exhale-Safeguarding our Future through Responsible Socio-Legal Policy on Marijuana, August, https://caricom. org/documents/report-of-the-caricom-regional-commission-on-marijuana-2018waiting-to-exhale-safeguarding-our-future-through-responsible-socio-legal-policyon-marijuana/ (accessed on 4 March 2019).

ClA (Cannabis Licensing Authority) (2017) Alternative Development (AD) Project. Including the Small Traditional Ganja Farmers in the Regulated Space, (Kingston: CLA), http://cla.org.jm/sites/default/files/documents/The\%2oAlternative\%2odevelopment\%2oProgramme_as\%2oat\%2oDecember\%202017.pdf (accessed on 4 March 2019). 
Dufton, E. (2017) Grass Roots. The Rise and Fall and Rise of Marijuana in America (New York: Basic Books).

Ehrlich, S.D. (2018) The Politics of Fair Trade. Moving Beyond Free Trade and Protection (Oxford: Oxford University Press).

EMCDDA (European Monitoring Centre for Drugs and Drug Addiction) (2018) Medical Use of Cannabis and Cannabinoids: Questions and Answers for Policymaking (Lisbon: EMCDDA).

European Union (2016) The Value of Geographical Indications for Businesses, European IPR Helpdesk, Fact Sheet, September 2016.

Ferguson, A. (2019) 'Accompong Ready to Plant 10 Acres of Ganja-Minister Says Small Farmers Won't Be Left Behind, The Gleaner, 29 April, http://jamaica-gleaner. com/article/news/20190429/accompong-ready-plant-10-acres-ganja-minister-sayssmall-farmers-wont-be-left (accessed on 11 October 2019).

Gilmore, K. (2018) Opening Statement by Kate Gilmore, Deputy High Commissioner OHCHR, Open-ended Intergovernmental Working Group on the Rights of Peasants and other People Working in Rural Areas, Fifth session, Geneva, 9-13 April, https://www.ohchr. org/en/NewsEvents/Pages/DisplayNews.aspx?NewsID=23014\&LangID=E (accessed on 4 March 2019).

Hall, W. (2018) 'A Summary of Reviews of Evidence on the Efficacy and Safety of Medical Use of Cannabis and Cannabinoids', Background paper commissioned by the EMCDDA for the report Medical Use of Cannabis and Cannabinoids: Questions and Answers for Policymaking (Lisbon: EMCDDA).

Holness, A. (2019) Andrew Holness at the Maroon celebration of the 281st signing of the treaty with the British and the birthday of Captain Kojo in Accompong Town, Twitter video @AndrewHolnessJM, 6 January, https://twitter.com/AndrewHolnessJM/status/1082689764380368896/video/1 (accessed on 4 March 2019).

Jamaican Observer (2019) 'Settle the CLA Matter', 7 October, http://www.jamaicaobserver.com/letters/settle-the-cla-matter_176556 (accessed on 11 October 2019).

Jamaica Observer (2018a) 'Barbados PM Comments on Decriminalisation of Marijuana', 8 December, http://www.jamaicaobserver.com/latestnews/_Barbados_PM_ comments_on_decriminalisation_of_marijuana (accessed on 4 March 2019).

Jamaica Observer (2018b) 'St Vincent Parliament Approves Legislation Decriminalising Marijuana', 14 December, http://www.jamaicaobserver.com/news/st-vincentparliament-approves-legislation-decriminalising-marijuana_152072 (accessed on 4 March 2019).

Jelsma, M., N. Boister, D. Bewley-Taylor, M. Fitzmaurice and J. Walsh (2018), Balancing Treaty Stability and Change: Inter se Modification of the UN drug Control Conventions to Facilitate Cannabis Regulation, wolA/TNI/GDPo Policy Report, March.

Jelsma, M., S. Kay and D. Bewley-Taylor (2019) Fair(er) Trade Options for the Cannabis Market (London/Swansea: Cannabis Innovate). 
Jones, S., R. Porter and C. Bishop (2017), 'The Implementation of Medical Ganja in Jamaica', International Journal of Drug Policy, 42, pp. 115-117.

Lamer, M. (2018), 'In a First, Africa Exports Medical Marijuana to Canada', Marijuana Business Daily, March 26, https://mjbizdaily.com/first-africa-exports-medicalmarijuana-canada/ (accessed on 11 October 2019).

Martínez Rivera, N. (2019) The Challenges of Medicinal Cannabis in Colombia-A Look at Small- and Medium-Scale Growers, Policy Briefing 52, October (Amsterdam: Transnational Institute).

Milman, O. (2017) 'Not so Green: How the Weed Industry is a Glutton for Fossil Fuels', The Guardian, 20 June, https://www.theguardian.com/society/2017/jun/20/ cannabis-climate-change-fossil-fuels (accessed on 7 December 2019).

NASEM (National Academies of Sciences, Engineering, and Medicine) (2017) The Health Effects of Cannabis and Cannabinoids: The Current State of Evidence and Recommendations for Research (Washington, DC: The National Academies Press).

Pascual, A. (2019) Cannabis in Latin America: The Regulations and Opportunities (Anne Holland Ventures: Marijuana Business Daily International).

Rendell, M. and T. Kiladze (2019) 'All Dried Up: How Bay Street Cashed in on the Cannabis Frenzy before the Carnage', 1 November, updated 4 November, The Globe and Mail, https://www.theglobeandmail.com/cannabis/article-all-dried-up-how-baystreet-cashed-in-on-the-cannabis-frenzy-before/ (accessed on 7 December 2019).

Subramaniam, V. (2019) 'In the Land with a Rich History of Growing Weed, Cannabis Capitalism is an Uneasy Fit', Financial Post, 5June, https://business.financialpost.com/cannabis/cannabis-business/jamaica-cannabis-business (accessed on 11 October 2019).

Tiffen, P. (2019) 'Who Cares about Fair Trade? An Introduction to the Journal of Fair Trade and the Fair Trade Society', The Journal of Fair Trade, 1(1), pp.1-5, https://www. joft.org.uk/wp-content/uploads/2019/o2/Tiffen.pdf (accessed on 18 May 2020).

Trefzer, A., J. T. Jackson, K. McKee and K. Dellinger (2014) 'Introduction: The Global South and/in the Global North: Interdisciplinary Investigations', The Global South, $8(2)$, pp. 1-15.

UN CND (UN Commission on Narcotic Drugs) (1958) Report to the Economic and Social Council on the Thirteenth Session (28 April-30 May 1958), Economic and Social Council, Official Records, 26th Session, Supplement No. 9, E/CN.7/354.

UN General Assembly (2016) Outcome Document of the 2016 United Nations General Assembly Special Session on the World Drug Problem-Our Joint Commitment to Effectively Addressing and Countering the World Drug Problem, Resolution adopted on 19 April 2016, A/REs/s-30/1.

UnODC (United Nations Office on Drugs and Crime) (2006), 'Cannabis: Why We Should Care', World Drug Report 2006, Vol. 1. Ch. 2, pp. 155-199 (New York: United Nations).

Walton, A. (2010) 'What is Fair Trade?', Third World Quarterly, 31(3), pp. 431-447. 
David Bewley-Taylor, Martin Jelsma, and Sylvia Kay - 9789004440494 Downloaded from Brill.come4/26/2023 10:44:22AM via free access 